\title{
Review Essay: \\ Slavoj Zizek: On Belief, and The Puppet and the Dwarf: The Perverse Core of Christianity
}

\author{
David Jasper
}

In his books On Belief (2001) and The Puppet and the Dwarf (2003), the philosopher and Lacanian psychoanalyst Slavoj Zizek poses the radical question of the nature and space of theology in the early twenty first century. Concerned fundamentally with the nature and presence of 'belief' in contemporary Western culture, Zizek is arguably, and paradoxically, one of the few genuinely Christian theologians writing today, to some extent, as we shall see, in the tradition of Thomas Altizer and the American "death of God' theology of the 1960s, while at the same time percolating Christian thinking through Socialist materialism and the psychoanalytic thinking of Lacan. Like Alain Badiou and others, he focuses specifically upon the Pauline community of believers rather than the Christianity of the canonical gospels, and draws upon a vast range of literature and film from within contemporary European culture.

Theology, for Zizek, is not a systematic endeavour. It is rather a cultural than a primarily philosophical enterprise, grounded for him in the nature of belief in the context of a contemporary, consumerist society. Yet, at the same time, specifically Christian theology, at its 'perverse core', he argues in On Belief, is the profoundly radical reversal of the religious pursuit of perfection, actually being about imperfection, affirming an entirely subjective understanding of Truth and opening up the possibility of the redemption of humanity by the purely human. In The Puppet and the DwarfZizek draws upon the rather unlikely figure of G. K. Chesterton and his book Orthodoxy (1908) to illustrate his belief that "the irrationalism of the late nineteenth century was the necessary consequence of the Enlightenment rational- 
ist attack on religion" (The Puppet and the Dwarf, p.47), and he quotes in a decidedly selective manner from Chesterton: "The outer ring of Christianity is a rigid guard of ethical abnegations and professional priests; but inside that inhuman guard you will find the old human life dancing like children, and drinking wine like men; for Christianity is the only frame for pagan freedom."

It is easy to place Zizek in the poetic and philosophical tradition that includes William Blake and Friedrich Nietzsche, with its celebration of the bodily as lying at the heart of the spiritual: and it is a tradition that is at once attractive and seductive. Who would not rather read a clever man like Zizek, who knows his philosophical tradition, and at the same time also finds interesting things to say about popular cinema - even The Sound of Music - and is therefore human like us: but human, all too human. For there is a tendency throughout these books to adopt the traditional language of Christianity (the imitatio Christi, for example, on page 105 of $O n$ Belief) and turn it into a way of describing a modus vivendi that also draws with reckless eclecticism from all forms of culture, both high and low, in a celebration of excess that finally looks more like surfeit and self-indulgence. Zizek is neither a systematic thinker, nor is he a poet, but he tends towards the temperament of the magpie, never allowing his readers a secure foothold. And yet I have presumed to call him a 'genuinely Christian theologian'. Why so?

First we might ask what he means by "the perverse core of Christianity" Through Lacan, and with, in the background, Nietzsche and The Communist Manifesto, Zizek offers this reading: "God first threw humanity into Sin in order to create the opportunity for saving it through Christ's sacrifice" (The Puppet and the Dwarf, p.53), confirming in a reading of The Lord of the Rings, Chesterton's apparent suggestion that "paganism is the ultimate Christian dream" (48). Religion, after Christ's sacrifice and having taken everything upon himself, becomes a safeguard "allowing us to enjoy life with impunity" (49). Of course, as always, one perversion begets another, and the price we pay for desire is desire itself. In the end, Zizek's version of Christianity actually appears to be rather like that of those fun-loving evangelicals who seem to imagine that all the thinking has been done for them and resolutely, and tiresomely, look forever on the bright side of life.

Of course this is a parody, but Zizek himself is endlessly parodic, and as in all good parodies there is enough truth at the heart of what he says to make him worth while reading. Of course it is possible to give a resolutely political reading of Christianity and the Pauline community as an antique revolutionary collective (provided you leave out large parts of his argument - Badiou is at least more up front when he admits that "I have never really connected Paul with religion....for me, Paul is a poet-thinker of the event, as well as one who practices and states the invariant traits of what can be called the militant figure" [Paul 1-2]). Why, then, can we call Zizek a genuinely Christian theologian? It is because he addresses a legitimate possibility for Christianity in a post-ecclesial, post-Christian age. He refuses to pursue the myth of Christian relevancy within the bounded dogmas of the Church, whose traditional authority, at least in the West, has effectively evaporated, leaving the Christian a homeless wanderer on the edges of the very culture that the Church has largely, in days gone by, constructed. Thinking about religion, to be serious, 
must take place in a world not dominated by traditional Christian symbols and liturgies, but by the popular cinema, Kinder Surprise eggs, multiculturalism and psychoanalysis - whether we like it or not. In this sense Zizek is seriously pursuing theological goals.

The problem is the lurking suspicion that there is something missing. Zizek is a clever, if rather untidy, thinker (though untidiness is not necessarily a deficit Martin Luther was as well). But clever people, as Paul, writing to the Corinthians, suggested, can sometimes miss the point. On the last page of The Puppet and the Dwarf Zizek signs up as a 'death of God' theologian, after Nietzsche, Thomas Altizer, et al. When Christ dies on the cross uttering his cry of dereliction, the secret hope that there is a godfather dies with him. At the core of Christianity is the abandonment by the 'big Other'. That is Zizek's version of the story. But the consequence of this is not necessarily another version of twentieth century materialism. It is something else, perhaps beyond even theology.

\section{Works Cited}

Alain Badiou. Saint Paul: The Foundation of Universalism. Trans. Ray Brassian. Stanford: Stanford UP, 2003. 